\title{
ISOLASI ZAT WARNA PADAT DARI LIMBAH KAYU ULIN
}

Oleh :

Haspiadi ${ }^{*}$

\begin{abstract}
This experiment was purposed to isolate the colouring powder from "ulin " wood waste. It has been done involved extraction process at the laboratory scale with water solvent. From the resuit show that, the yield of extractives by purification was small, generally up to $6,12-7,98 \%$. However, without the purification after axtraction relatively high, generally up to $9,64-12,82 \%$ because of contain impurities that are soluble in hexane.
\end{abstract}

Key words : 'ulin'wood waste, extractives, colouring powder

\section{PENDAHULUAN}

Kayu ulin (Belian, Kayu Besi atau Onglen) dengan nama latin Eusederoxylon Zwagerii merupakan famili Lauraceae yang merupakan kayu dengan nilai jual cukup tinggi karena ketahanan terhadap cuaca serta air. Kayu ulin bila terendam daiam air akan meninggalkan warna merah coklat. Zat warna tersebut dihasilkan dari kuiit kayu dan kayunya sendiri dengan jenis Eusiderin (Andayani T. dkk 2002).

Penggunaan kayu ulin sebagian besar sebagai tiang rumah, tiang pondasi, jembatan dan bantalan kereta api. Namun dalam pemanfaatannya tidak semua dapat termanfaatkan secara utuh tetapi masih menyisakan limbah berupa potongan-potongan kecil baik berupa chip maupun serbuk dalam jumlah yang cukup banyak.

Didukung oleh ketersediaan bahan baku yang cukup melimpah dalam bentuk limbah padat yang dihasilkan dari pemanfaatan kayu ulin sebagai bahan bangunan, serta data yang diperoleh dari Pusat Penelitian Hutan Tropis UNMUL untuk tahun 2002 di mana produksi kayu ulin yang dikelolah $12 \mathrm{HPH}$ hingga tahun 2001 rata-rata $37.788,93 \mathrm{~m} 3$ sehingga pemanfaatan limbah padat kayu tersebut memiliki potensi yang cukup baik.

Penelitian terdahulu telah dilakukan untuk mengembangkan zat warna kayu ulin dimana didapatkan zat warna dalam bentuk larutan yang diekstrak dari potongan-potongan kayu dan digunakan langsung sebagai pewarna pada kain ulap doyo (Anonim, 2002). Namun dilihat dari sifat anatomis kayu ulin dimana zat warna kayu ulin mudah teroksidasi sehingga dalam penelitian ini dilakukan penelitian lanjut skala laboratorium untuk mendapatkan zat warna dalam bentuk padat.

Diharapkan zat warna kayu ulin dalam bentuk padat atau bubuk sifatnya dapat lebih stabil serta effisien dalam penanganan sehingga dapat digunakan secara luas. Tidak hanya pewarna dalam bentuk larutan ektrak, tetapi dapat diperoleh dalam bentuk pewarna padat yang memiliki sifat ketahanan dibandingkan dalam bentuk cair sebagaimana sifat dari zat warna yang terkandung pada kayu ulin tersebut.

Didapatkannya zat warna dalam bentuk padat bukan tidak mungkin dapat meningkatkan nilai tambah limbah kayu ulin yang selama ini belum dimanfaatkan secara optimal bila dibandingkan zat warna dalam bentuk ektrak cair. Pada penelitian ini proses ekstraksi dan isolasi limbah kayu ulin yang dilakukan hanya pada lingkup untuk mendapatkan zat warna padat saja tanpa dilanjutkan identifikasi zat warnanya secara kimia. 


\section{BAHAN DAN METODE}

Bahan yang digunakan dalam penelitian ini adalah limbah kayu ulin yang dihasilkan dari kegiatan pemanfaatan kayu ulin pada industri moulding dalam bentuk serbuk dengan ukuran ratarata kurang dari $5 \mathrm{~mm}$ diameter, selanjutnya dikeringkan pada kondisi udara atmosfir untuk menghindari zat warna terdegradasi. Sedangkan peralatan yang digunakan adaiah seperangkat alat ekstraksi skala laboratorium.

Penelitian diawali dengan mengumpulkan bahan dari berbagai tempat pengolahan pemanfaatan kayu ulin kemudian ditimbang sebanyak kurang lebih 40 gram dan selanjutnya dimasukkan kedalam alat ekstraksi dan diektraksi menggunakan pelarut air sebanyak $500 \mathrm{~mL}$. Proses ektraksi dilakukan dengan variabel waktu 3,6 dan 9 jam. Untuk mengatasi berkurangnya pelarut akibat adanya penguapan maka penambahan air dilakukan hingga volume tetap.

Setelah proses ektraksi berakhir ke dalam eksudat kayu ulin tersebut ditambahkan sodium hidroksida $(\mathrm{NaOH})$ 1\% 1:20 untuk membantu mengoptimalkan pelepasan zat warna kemudian disaring. Eksudat kayu dari dua kali proses salah satunya dilajutkandengan pemurnian dan yang lain tanpa pemurnian. Untuk proses tanpa pemurnian langsung diisolasi dengan cara penguapan di atas penangas air hingga diperoleh padatan dalam bentuk bubuk dan ditimbang.

Sedangkan untuk proses pemurnian dilakukan dengan ekstraksi lanjut menggunakan pelarut $\mathrm{n}$-hexane sebayak $75 \mathrm{~mL}$ dan dikocok hingga bercampur sempurna, kemudian didiamkan beberapa menit hingga terbentuk dua lapisan yaitu fasa cair dan fasa pelarut. Fasa cair yang mengandung zat warna diambil kemudian diuapkan dengan pemanas air sedangkan fasa pelarut yang kaya akan zat-zat penyusun kayu seperti lignin dan lain-lain dibuang. Setelah air menguap semua kemudian ditimbang untuk mengetahui rendemen yang dihasilkan dan dianalisa, kadar air, pengamatan dan bentuk butiran dan pada tahap akhir dilakukan uji coba pemanfaataan zat warna tersebut dengan air dan plitur bening.

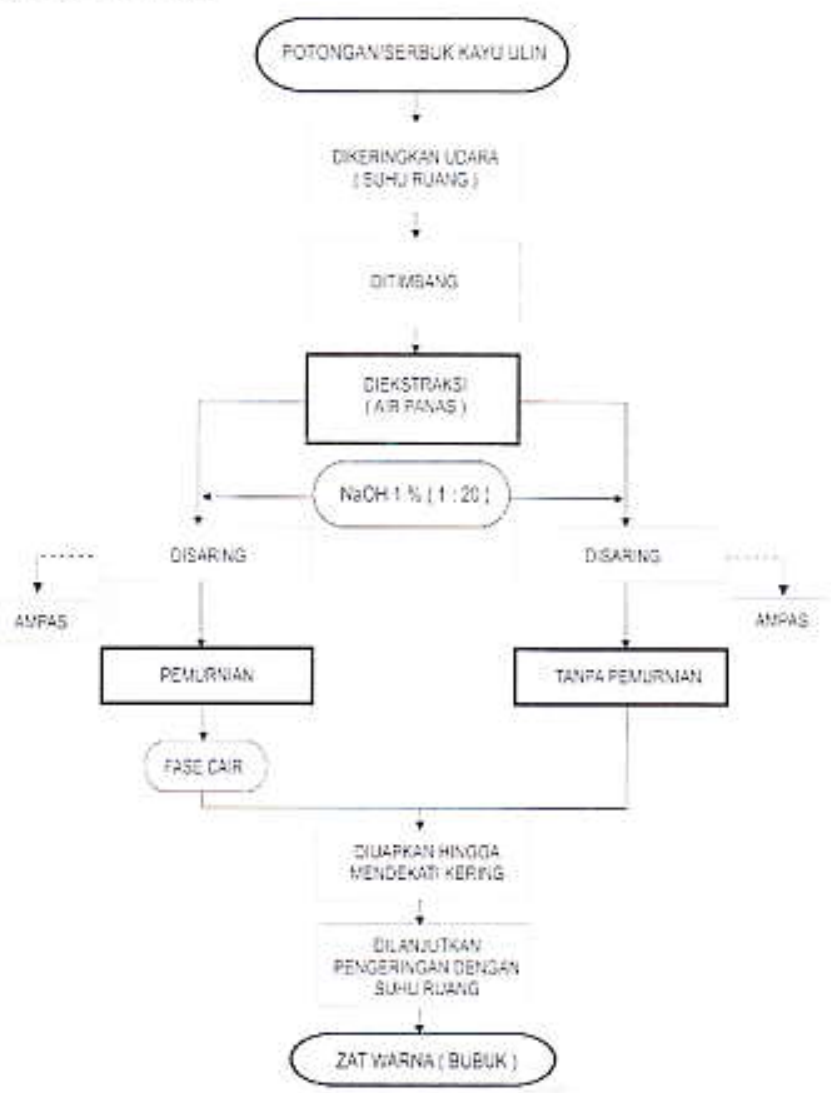

Gambar 1. Diagram Alir Proses Ekstraksi dan Isolasi Zat Warna dari Limbah Padat Kayu Ulin 


\section{HASILDAN PEMBAHASAN}

Penelitian skala laboratorium dilakukan dengan cara ekstraksi untuk mendapatkan zat warna padat. Zat warna padat diperoleh setelah dilakukan pemisahan antara cairan dan padatan dengan cara penguapan fasa cair hasil ekstraksi. Ektraksi dilakukan dua kali untuk pemurnian dan tanpa pemurnian.

Pemurnian dimaksudkan untuk menghilangkan pengotor atau senyawa-senyawa kimia yang dapat mempengaruhi kualitas zat warna padat. Sedangkan perlakuan tanpa pemurnian untuk mengetahui adanya pengaruh senyawa-senyawa kimia penyusun kayu terhadap prosentase zat warna yang dihasilkan.

Ekstraksi menggunakan pelarut air dikarenakan air adalah pelarut netral yang murah serta mudah di diperoleh. Hal terpenting selain dijelaskan di atas adalah sifat dari senyawa-senyawa kayu yang tidak banyak larut di dalam air sebagaimana dijelaskan oleh Sjostrom. E (1995) dalam bukunya, sehingga diharapkan tidak banyak berpengaruh terhadap kualitas butiran zat warna.

Berdasarkan sifat kelarutan kayu ulin yang baik dalam air adalah 5,2\% dan $\mathrm{NaOH} 1 \% 16,4 \%$ (Sudrajat, 1979), maka dalam penelitian ini juga dilakukan penambahan $\mathrm{NaOH} 1 \%(1: 20)$ untuk membantu memperbesar daya larut zat warna sebelum disaring. Adapun data hasil penelitian yang telah dilakukan seperti tertera pada tabel 2 . di bawah.

Tabel 2. Data Hasil Penelitian

\begin{tabular}{|c|c|c|c|c|c|c|}
\hline \multirow[b]{2}{*}{ No. } & \multicolumn{2}{|c|}{ KOMBINASI PERLAKUAN } & \multirow[b]{2}{*}{$\begin{array}{l}\text { KADAR } \\
\text { AIR }(\%)\end{array}$} & \multirow{2}{*}{$\begin{array}{c}\text { RENDEMEN } \\
(\%) \\
\text { (BERAT } \\
\text { KOTOR) }\end{array}$} & \multirow[b]{2}{*}{$\begin{array}{l}\text { WARNA } \\
\text { (VISUAL) }\end{array}$} & \multirow[b]{2}{*}{ BENTUK } \\
\hline & - & $\begin{array}{c}\text { WAKTU } \\
\text { EKSTRAKSI } \\
\text { (jam) }\end{array}$ & & & & \\
\hline \multirow{3}{*}{1.} & \multirow{3}{*}{$\begin{array}{c}\text { Tanpa } \\
\text { Pemurnian }\end{array}$} & 3 & 0,75 & 9,64 & Coklat & $\begin{array}{c}\text { Bubuk sedikit } \\
\text { kristal }\end{array}$ \\
\hline & & 6 & 0,65 & 12,82 & Coklat & $\begin{array}{c}\text { Bubuk sedikit } \\
\text { kristal }\end{array}$ \\
\hline & & 9 & 0,82 & 12,36 & $\begin{array}{c}\text { Coklat } \\
\text { kehitaman }\end{array}$ & $\begin{array}{c}\text { Bubuk sedikit } \\
\text { kristal }\end{array}$ \\
\hline \multirow{3}{*}{2.} & \multirow{3}{*}{ Pemurnian } & 3 & 0,51 & 6,12 & $\begin{array}{c}\text { Coklat } \\
\text { kekuningan }\end{array}$ & Bubuk halus \\
\hline & & 6 & 0,57 & 6,50 & $\begin{array}{c}\text { Coklat } \\
\text { kekuningan }\end{array}$ & Bubuk halus \\
\hline & & 9 & 0,49 & 7,98 & $\begin{array}{c}\text { Coklat } \\
\text { kehitaman }\end{array}$ & Bubuk halus \\
\hline
\end{tabular}

Pemilihan waktu ekstraksi yang dilakukan dengan lama ekstraksi 3, 6 dan 9 jam atas dasar teori yang menurut Preosedur Standar TAPPI (Test Methods Technical Association of the Pulp and Paper Industry) bahwa waktu yang optimal untuk ekstraksi kayu adalah 4 sampai dengan 8 jam, sehingga diharapkan rentang pengaturan waktu ekstraksi tersebut dapat dengan optimal untuk mendapatkan zat warna dari kayu ulin.

Zat warna padat yang dihasilkan dari proses baik tanpa pemurnian maupun pemurnian dikeringkan dalam suhu ruang dengan kadar air untuk proses tanpa pemurnian $0,75 \%, 0,65 \%$ dan $0,82 \%$ dihasilkan dari waktu ekstraksi berturut- turut 3,6 dan 9 jam, serta $0,51 \%, 0,57 \%$ dan $0,49 \%$ dengan waktu ekstraksi 3,6 dan 9 jam. Dari kadar air ini terlihat kecenderungan kadar air dengan pemurnian lebih rendah dibandingkan dengan tanpa pemurnian. Sedangkan diameter dari bubuk 
warna iolos ukuran 8 mesh.

Hasil percobaan menunjukkan bahwa secara umum dari ketiga variabel waktu, untuk perlakuan tanpa pemurnian rendemennya jauh lebih besar dibandingkan dengan pemurnian yaitu rata-rata 2 kali lebih besar untuk waktu ekstraksi 6 dan 9 jam. Hal ini dikarenakan tanpa pemurnian selain zat warna yang terlarut juga senyawa-senyawa kimia penyusun kayu seperti resin, asam lemak, senyawa eter dan getah kayu juga ikut terlarut pada suhu tinggi walaupun dalam jumlah yang kecii.

Sedangkan untuk waktu ektraksi 3 jam rendemen yang dihasilkan hanya $9,64 \%$, jauh lebih kecil dibandingkan dengan waktu ekstraksi 6 dan 9 jam. Rendahnya rendemen pada waktu ekstraksi 3 jam dapat disebabkan oleh zat-zat warna yang ada belum sepenuhnya dapat terlarut dalam pelarut air.

Berbeda dengan tanpa pemurnian, rendemen yang dihasilkan dengan pemurnian untuk waktu ekstraksi 3, 6 dan 9 jam kecil yaitu hanya $6,12 \%, 6,50 \%$ dan $7,98 \%$. Kecilnya rendemennya yang dihasilkan dapat disebabkan oleh proses pemurnian dengan n-hexane yang mengikat senyawa-senyawa kimia seperti seperti resin, asam lemak, senyawa eter dan getah kayu. Dari percobaan terlihat fraksi pelarut (n-hexan) memiliki bentuk padat berwarna putih bening sedangkan fasa air (fasa zat warna) warnanya justru coklat terang.

Proses dengan pemurnian dari ketiga waktu ekstraksi yang berbeda yaitu 3,6 dan 9 jam, rendemen tertinggi diperoieh pada waktu ekstraksi 9 jam sedangkan untuk 3 dan 6 jam rendemennya tidak begitu besar perbedaanya yaitu hanya $0,38 \%$. Sehingga secara umum setelah pemurnian dapat dilihat rendemen hasil yang relatif sama dapat menggambarkan bahwa pada proses tanpa pemurnian jumlah pengotor berpengaruh terhadap jumlah hasil yang diperoleh.

Zat warna yang diamati secara visual merupakan kondisi kering, baik dengan perlakuan pemurnian maupun tanpa pemurnian, kenampakan warnanya berbeda. Seperti perlakuan tanpa pemurnian untuk waktu ekstraksi 3 dan 6 jam warna yang tampak adalah coklat, berbeda dengan waktu 9 jam warna zat padat adalah coklat kehitaman. Sedangkan dengan perlakuan pemurnian, dimana waktu ektraksi 3 dan 6 jam penampakan warna sama yaitu coklat kekuningan sedangkan waktu ekstraksi 9 jam berbeda yaitu coklat kehitaman. Adanya perbedaan warna khususnya Tabel 3. Hasil Uji Caba Pewarnaan waktu ekstraksi 9 jam dapat disebabkan oleh pengaruh oksidasi dan suhu air sebagaimana dijelaskan oleh David N.S dan Minemura N (2001) dalam bukunya. Selain itu menurunnya warna coklat yang diamati secara visual hasil dari pemurnian dapat disebabkan oleh komponen kimia kayu yang terserap setelah dimurnikan dengan pelarut sehingga mempengaruhi interaksi warna terhadap cahaya.

Proses ekstraksi untuk mendapatkan zat warna padatan menghasilkan zat warna dengan bentuk yang berbeda antara pemurnian dengan tanpa pemurnian. Bubuk zat warna yang melalui pemurnian menghasilkan bubuk yang halus, sedangkan tanpa pemurnian zat warna yang terbentuk selain bubuk halus juga terdapat kristal-kristal kecil yang padat untuk masing-masing waktu ektraksi 3, 6 dan 9 jam. Kristal-kristal yang terbentuk dalam percobaan pencampuran dengan pelarut cat baik air maupun cat minyak diduga disebabkan oleh kandungan selulosa, hemiselulosa dan lignin yang terlarut dalam proses ektraksi sebagaimana dijelaskan oleh (Umezawa T. dalam David N. S dan Shiraishi N., 2001) bahwa selama dalam proses ekstraksi senyawa kimia kayu dapat terlarut khususnya tannin yang memiliki sifat kelarutan dalam air sangat baik.

Zat warna hasil isolasi baik tanpa pemurnian maupun dengan pemurnian di uji cobakan 
dengan melarutkan dalam dua jenis pelarut yaitu air dan vernis. Hasil uji coba seperti padat table 3.

Hasil pengamatan secara visual menunjukkan sifat kelarutan yang berbeda dalam air dan vernis., dimana dalam air sifat kelarutannya dilihat dari kesempurnaan tanpa adanya butiran atau padatan tersisa baik pemurnian maupun proses tanpa pemurnian, sedangkan dalam cairan vernis kelarutannya masi menyisahkan padatan-padatan halus sekitar 10 sampai dengan $12 \%$ setelah dicampurkan dan diaduk. Demikian pula untuk proses dengan pemurnian menyisakan butiran halus sekitar 5 sampai dengan $6 \%$ setelah dicampur dan diaduk.

Tabel 3. Hasil Uji Caba Pewarnaan

\begin{tabular}{|c|c|c|c|c|}
\hline \multirow[b]{2}{*}{ No. } & \multicolumn{2}{|c|}{ KOMBINASI PERLAKUAN } & \multicolumn{2}{|c|}{ SIFAT KELARUTAN DALAM } \\
\hline & 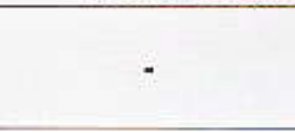 & $\begin{array}{c}\text { WAKTU } \\
\text { EKSTRAKSI } \\
\text { (jam) }\end{array}$ & AIR & VERNIS \\
\hline \multirow{3}{*}{1} & \multirow{3}{*}{ Tanpa Pemurnian } & 0 & Larut & $\begin{array}{l}\text { Terdapat butir-butir } \\
\text { halus }\end{array}$ \\
\hline & & 6 & Larut & $\begin{array}{l}\text { Terdapat butir-butir } \\
\text { halus }\end{array}$ \\
\hline & & 9 & Larut & $\begin{array}{l}\text { Terdapat butir-butir } \\
\text { halus }\end{array}$ \\
\hline \multirow{3}{*}{2} & \multirow{3}{*}{ Pemurnian } & 3 & Larut & $\begin{array}{l}\text { Terdapat butir-butir } \\
\text { halus }\end{array}$ \\
\hline & & 6 & Larut & $\begin{array}{c}\text { Terdapat butir-butir } \\
\text { halus }\end{array}$ \\
\hline & & 9 & Larut & $\begin{array}{l}\text { Terdapat butir-butir } \\
\text { halus }\end{array}$ \\
\hline
\end{tabular}

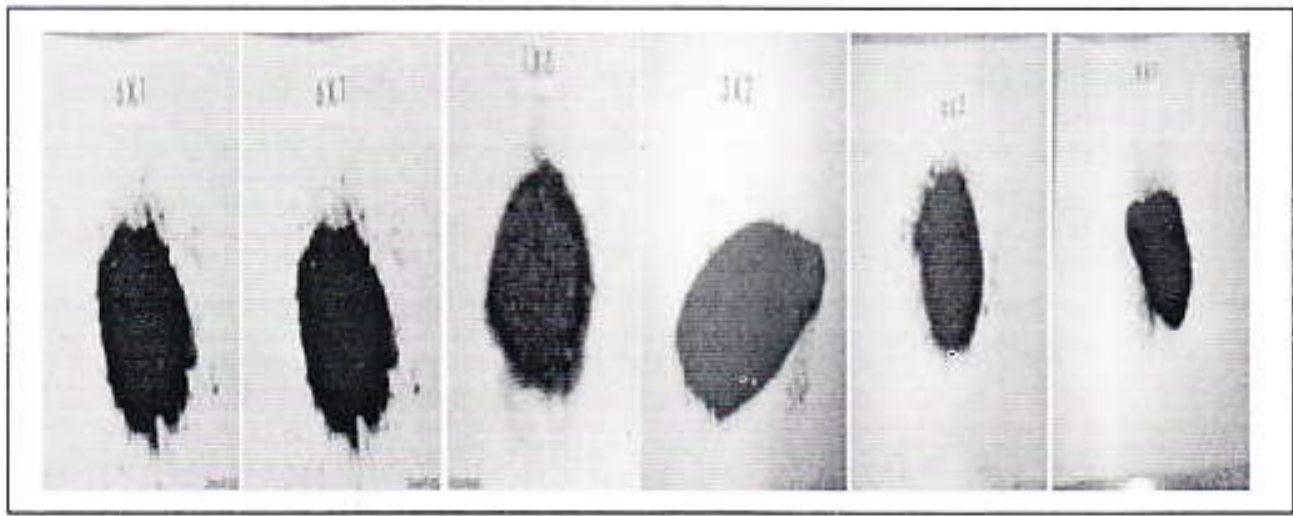

Gambar 3. Bentuk Zat Warna Padat (Bubuk) dari Limbah Kayu Ulin

\section{KESIMPULAN DAN SARAN}

Zat warna yang terkandung dalam kayu ulin dapat diekstrak untuk mendapatkan zat warna dalam bentuk padat. Secara umum berdasarkan karakteristik zat warna padat yang dihasilkan proses pemurnian dengan waktu ekstraksi 9 jam merupakan yang terbaik berdasarkan warna visual yaitu coklat kehitaman, bubuk halus dan rendemen tertinggi yaitu $7,98 \%$, sedangkan tanpa pemurnian walaupun dihasilkan rendemen tertinggi $12,82 \%$ dengan waktu ekstraksi 6 jam namun bentuk yang sedikit kristal.

Dalam pemilihan limbah padat kayu ulin sebaiknya limbah yang belum bercampur atau terendam air agar rendemen yang dihasilkan dapat lebih besar serta warna yang dihasilkan akan lebih baik. 


\section{DAFTAR PUSTAKA}

Sudrajat .1979. Analisis Kimia Beberapa Jenis Kayu Indonesia

Sjostrom. E., 1995. Kimia Kayu. Dasar-dasardan Penggunaan

Umezawa T., Chemistry of Extractives, Kyoto University Japan dalam "Wood and Cellulosic

Chemistry" second edition, reseived and expanded by David N. S. Hon dan Nobuo Shiraishi, 2001.

David N.S. Hon dan Nobuya Minemura 2001 Color and Discoloration dalam "Wood and Cellulosic Chemistry" second edition, reseived and expanded by by David N. S dan Shiraishi N, 2001. Andayani T. dan kawan-kawan 2002 Penelitian dan Pengembangan Zat Warna Kayu Ulin 